\section{Stable isotopic and chemical indicators of volcanic eruptions in tree rings from Parícutin, Mexico}

\author{
Christine A.M. France, ${ }^{1}$ \\ Paul R. Sheppard, ${ }^{2}$ Nadia Cano, ${ }^{1}$ \\ Nicole C. Little, ${ }^{1}$ Robert J. Speakman ${ }^{1}$ \\ 'Smithsonian Museum Conservation \\ Institute, Suitland, MD; ${ }^{2}$ Laboratory or \\ Tree Ring Research, University of \\ Arizona, Tucson, AZ, USA
}

\section{Abstract}

Annual growth rings obtained from well dated tree ring cores from Parícutin, Mexico are examined for unique chemical signatures that reflect a known local volcanic eruption and its subsequent atmospheric and terrestrial inputs. Stable carbon isotopic profiles are combined with elemental analyses to construct a chemical profile before, during, and after the known eruptive years (1943-1952) when a cinder cone formed near the town of Parícutin. Data from this well documented eruption are combined with controls obtained from outside the ash fall zone. Carbon isotopes exhibit an enriched spike $(\sim 3 \%)$ during the eruptive period followed by a subsequent return to baseline values. This in combination with other stable isotopic indicators and increases in phosphorus, sulfur, and possibly other elements, suggest a unique set of chemical inputs from the eruption. The analytical approach developed here potentially can be used to date unknown eruptions which in the past have often relied on the common dendrochronologic technique of tree ring width determination, or on historic human records. The former method can be somewhat subjective as changes in ring width can be attributed to multiple causes in addition to volcanically induced environmental stresses; the latter method is restricted to eruptions occurring in the last few thousand years. The quantitative approach of chemical analyses presented in this preliminary study can potentially be combined with standard dendrochronological and/or ${ }^{14} \mathrm{C}$ dating to accurately identify eruption events and place them in an anthropologic context.

\section{Introduction}

Understanding of environmental perturbations is critical to the study of ancient human populations in the sense that catastrophic events affect living conditions and often result in forced adaptations or migrations. Volcanic eruptions in particular are highly catastrophic events that have a profound effect on the surrounding populations as evidenced by well known examples such as the eruption of Mt. Vesuvius near Pompeii in 79 AD or the eruption of Mt. Saint Helens in the Pacific Northwest in 1980. Although some volcanic eruptions are well dated and have an accurate recorded history, many do not and their subsequent effect on local populations from an anthropologic viewpoint cannot be determined. This preliminary study focuses on establishing a suite of geochemical indicators recorded in tree rings that can be correlated to traditional dendrochronological and/or ${ }^{14} \mathrm{C}$ dates for the purpose of identifying and dating volcanic eruptions.

Both elemental abundances and stable isotopic signatures within tree rings are good indicators of environmental perturbations. Elevated abundances of elemental phosphorus, magnesium, sulfur, and other elements represent input from volcanic ash and disturbed soils as these elements are found in relatively higher abundances in these substances (Rose, 1977; Smith et al., 1982; de Moor et al., 2010). The stable isotopic signatures of carbon, sulfur, and oxygen tend to be very unique in volcanic gases and ash as compared to the atmospheric reservoir and surface sediments (Tazieff and Sabroux, 1983). Compounds containing these elements $\left(\right.$ e.g. $\left.\mathrm{CO}_{2}, \mathrm{SO}_{2}, \mathrm{O}_{2}\right)$ are released during eruptions and are eventually incorporated into the local atmosphere and vegetation, thus carrying their characteristic isotopic signatures with them. Volcanic eruptions can also affect environmental conditions such that isotopic discrimination during formation of plant tissues and elemental uptake by plants is altered (Farquhar et al., 1982, 1989; Tieszen, 1991; Holford, 1997; Heaton, 1999). It is most probable that several of these factors function together to produce isotopic and elemental spikes in the tree rings formed during eruption events.

This geochemical approach is applied here to a well-dated eruption from Parícutin, Mexico in an effort to establish a preliminary chemical profile representative of volcanic activity as recorded in tree rings. The Parícutin cinder cone, part of the TransMexican Volcanic Belt, began erupting in 1943 and continued until 1952 (Luhr and Simkin, 1995). As of its last known eruption, the ash and pyroclastic debris zone covered $\sim 25 \mathrm{~km}^{2}$ and enveloped a nearby town (Figure 1). The precise documentation of this eruption and its timing renders it an excellent case study for alternative methods of dating ancient volcanic events. Cores obtained from pine trees within the ash fall zone provide a series of well dated rings that can be tested for unique chemical signatures within rings grown during 19431952.
Correspondence: Christine France, Smithsonian Museum Conservation Institute, 4210 Silver Hill Rd., 20746 Suitland, MD, USA.

Tel. +1.301.238.1261 - Fax: +1.301.238.3709.

E-mail: francec@si.edu

Key words: stable isotopes, dendrochronology, ICP-MS.

Acknowledgements: all isotopic analyses were performed at the Smithsonian OUSS/MCI Stable Isotope Mass Spectrometry Facility. All ICP-MS analyses were performed at the University of Missouri Research Reactor. The authors thank Mark Elson and Michael Ort for their assistance with earlier phases of this research.

Citation: France CAM, Sheppard PR, Cano N, Little NC, Speakman RJ, 2014. Stable isotopic and chemical indicators of volcanic eruptions in tree rings from Parícutin, Mexico. In: RH Tykot (ed.), Proceedings of the $38^{\text {th }}$ International Symposium on Archaeometry - May $10^{\text {th }}-14^{\text {th }}$ 2010, Tampa, Florida. Open Journal of Archaeometry 2:5261.

Presented at the $38^{\text {th }}$ International Symposium on Archaeometry - May $10^{\text {th }}-14^{\text {th }} 2010$, Tampa, Florida.

This work is licensed under a Creative Commons Attribution 3.0 License (by-nc 3.0).

(C) Copyright C.A.M. France et al., 2014

Licensee PAGEPress, Italy

Open Journal of Archaeometry 2014; 2:5261

doi:10.4081/arc.2014.5261

\section{Materials and Methods}

Several cores from pine trees (Pinus leiophylla, P. pseudosrobus, $P$. mentezumae, and $P$. teocote) located in the ash fall zone immediately adjacent to the Parícutin cinder cone and cores $\sim 5 \mathrm{~km}$ distant in the town of Tancitaro are examined for chemical signatures that reflect the eruption (Figure 1). Standard dendrochronological and microscopy methods have identified, dated, and measured the exact tree rings that formed before, during, and after the eruption (Sheppard et al., 2008). Samples from the individual tree rings concurrent with eruptive years as well as pre- and post- eruptive years were obtained using a common Dremel tool and/or razor blade to extract a whole wood sample (both early and late wood) from each individual ring which was then homogenized to represent one year of growth. For carbon isotopic measurements, whole wood samples are much more expedient to process and the data correlates directly to cellulose extractions (a method commonly used for isotopic measurements of tree rings). For this reason whole wood was used in order to facilitate sampling in greater number with 
rapid throughput.

Elemental abundances of sulfur and phosphorus were analyzed in solution using a VG Elemental Axiom magnetic sector ICP-MS. Complete sample preparation methods and data from these analyses are originally published in Sheppard et al. (2008) and are reanalyzed and reproduced here. In brief, samples were freeze-dried to a constant weight and then weighed into precleaned, pre-weighed, trace-metal free polypropylene centrifuge tubes. For every $25 \mathrm{mg}$ of sample, $1 \mathrm{~mL}$ of concentrated Fisher brand Optima grade nitric acid $\left(\mathrm{HNO}_{3}\right)$ was added to the tube. Samples were digested at room temperature for three days and then heated to $70 \mathrm{C}$ in an ultrasonic bath for three hours to complete digestion. Aliquots were diluted with ultra-pure water and spiked with internal standards (Sc, Nd, In). Data are calibrated using a series of linearity standards.

Stable carbon isotopic measurements were performed on a Costech 4010 Elemental Analyzer connected to a Thermo Delta V Advantage continuous flow mass spectrometer via a Conflo IV interface. Samples were introduced as whole wood shavings packed into tin cups. Data are reported in standard delta notation $\left[\delta=\left(\left(R_{\text {sample }} / R_{\text {standard }}\right)-1\right) * 1000\right.$ where $R$ is the ${ }^{13} \mathrm{C} /{ }^{2} \mathrm{C}$ ratio, units are permil, and the standard is Vienna Pee Dee Belemnite. The error on all $\delta^{13} \mathrm{C}$ data is $\pm 0.2 \%$ ( $\left.1 \sigma\right)$.

Table 1. Carbon isotopic, phosphorus, and sulfur concentration data.

\begin{tabular}{|c|c|c|c|c|c|c|c|c|}
\hline \multirow{2}{*}{ Year } & \multicolumn{2}{|c|}{$\delta^{13} \mathrm{C}(\% 0, \mathrm{~V}-\mathrm{PDB})$} & \multicolumn{3}{|c|}{ Phosphorus concentration (ppm) } & \multicolumn{3}{|c|}{ Sulfur concentration (ppm) } \\
\hline & Rosetta & Tancitaro & Rosetta & PAA11A & Tancitaro & Rosetta & PAA12A & Tancitaro \\
\hline 1927 & -24.3 & - & & & & & & \\
\hline 1928 & -24.2 & - & 4.9 & & & 94.7 & & \\
\hline 1929 & -24.8 & - & 6.9 & & & 79.9 & & \\
\hline 1930 & -25.2 & - & 8.3 & & & 103.5 & & \\
\hline 1931 & -25.1 & - & 4.9 & & & 79.2 & & \\
\hline 1932 & -24.8 & - & 1.9 & & & 71.9 & & \\
\hline 1933 & -24.9 & -23.4 & 3.8 & & & 80.2 & & \\
\hline 1934 & -25.3 & -23.3 & 0.8 & & & 72.6 & & \\
\hline 1935 & -24.9 & -25.2 & 2.5 & & 17.2 & 75.5 & & 141.9 \\
\hline 1936 & -25.4 & -24.7 & 1.4 & 6.4 & 6.4 & 59.2 & & 64.6 \\
\hline 1937 & -25.8 & -24.1 & 4.1 & 6.1 & 8.5 & 107.7 & & 89.5 \\
\hline 1938 & -25.6 & -24.6 & 0.0 & 4.0 & 7.2 & 67.9 & 160.1 & 85.8 \\
\hline 1939 & -25.1 & -24.3 & 1.4 & 7.8 & 7.5 & 72.7 & 163.3 & 116.4 \\
\hline 1940 & -25.0 & -24.5 & 1.1 & 10.2 & 9.7 & 67.2 & 196.8 & 97.2 \\
\hline 1941 & -25.0 & -24.5 & 1.4 & 7.6 & 10.8 & 88.1 & 189.5 & 91.8 \\
\hline 1942 & -25.1 & -22.3 & 4.4 & 6.5 & 6.4 & 252.1 & 202.7 & 68.7 \\
\hline 1943 & -23.3 & -23.3 & 0.1 & 9.4 & 7.0 & 69.3 & 295.9 & 90.3 \\
\hline 1944 & -23.3 & -24.8 & 5.7 & 23.1 & 8.4 & 130.1 & 274.1 & 81.7 \\
\hline 1945 & -22.9 & -24.8 & 11.7 & 30.1 & 4.4 & 186.9 & 134.0 & 95.7 \\
\hline 1946 & -23.6 & -24.7 & 35.9 & 29.3 & 10.0 & 317.6 & 187.7 & 101.9 \\
\hline 1947 & -23.6 & -24.2 & 13.0 & 20.4 & 6.7 & 265.7 & 195.7 & 104.6 \\
\hline 1948 & -24.3 & -24.6 & 15.5 & 11.8 & 12.5 & 284.2 & 216.3 & 121.3 \\
\hline 1949 & -22.9 & -24.2 & 9.9 & 12.7 & 12.1 & 242.0 & 193.4 & 119.0 \\
\hline 1950 & -21.9 & -24.9 & 7.6 & 26.4 & 10.7 & 303.2 & 196.1 & 108.4 \\
\hline 1951 & -22.3 & -24.2 & 3.8 & 14.2 & 12.8 & 136.7 & 386.3 & 80.4 \\
\hline 1952 & -22.7 & -24.0 & 10.5 & 14.2 & 14.3 & 346.1 & 179.9 & 73.6 \\
\hline 1953 & -23.1 & -22.5 & 8.1 & 14.7 & 10.9 & 182.9 & 180.9 & 58.9 \\
\hline 1954 & -24.5 & -21.9 & 5.7 & 14.4 & 14.1 & 95.4 & 226.0 & 77.0 \\
\hline 1955 & -23.4 & -23.1 & 5.7 & 19.4 & 8.3 & 186.9 & 159.2 & 66.7 \\
\hline 1956 & -24.1 & -23.6 & & 14.9 & 7.2 & & 238.6 & 80.0 \\
\hline 1957 & -23.0 & -22.7 & & 13.0 & 5.7 & & 318.7 & 79.9 \\
\hline 1958 & -23.7 & -22.6 & & 13.4 & 10.5 & & 175.0 & 81.7 \\
\hline 1959 & -24.6 & -23.4 & & 15.8 & 7.1 & & 164.1 & 77.9 \\
\hline 1960 & -24.7 & -22.7 & & 9.5 & 13.6 & & 145.3 & 81.4 \\
\hline 1961 & -24.4 & -22.9 & & 11.5 & 12.7 & & 178.0 & 120.1 \\
\hline 1962 & -24.7 & -23.7 & & 13.9 & 10.8 & & 151.4 & 105.8 \\
\hline 1963 & -24.2 & -23.9 & & 8.7 & 10.0 & & 180.2 & 114.5 \\
\hline 1964 & -24.0 & -24.0 & & 15.8 & 37.9 & & 178.2 & 235.7 \\
\hline
\end{tabular}

V-PDB, Vienna-Pee-Dee Belemnite standard; PAA11A, Parícutin ash fall zone 1; PAA12A, Parícutin ash fall zone 2. 


\section{Results}

Previous analyses of tree ring widths from the Paricutin cores show varying patterns during eruptive years (Sheppard et al., 2008). Rings in the Rosetta stump show a narrowing of width and higher inter-annual variability during the eruption. Additionally this core shows alignment of resin ducts and false-ring bands, both of which are interpreted to indicate external disturbances and stresses (Sheppard et al., 2008). It should be noted that additional cores within the Paricutin ash fall zone (i.e. PAA11A and PAA12A) do not show this ring width variability despite the indications of chemical variability as outlined below, thereby indicating that ring width measurements alone are insufficient to identify volcanic periods in a tree's lifespan.

Carbon isotopic analyses of tree cores, immediately adjacent to and in the ash-fall zone of the eruption, show enrichment during the eruptive years (Table 1, Figure 2). The average $\delta^{13} \mathrm{C}$ value for the years $1943-1952$ is significantly more enriched than the previous years (2-tailed t-test, $\alpha=0.05$ ). Cores taken at a distance of about $5 \mathrm{~km}$ from the eruption show an equivalent $\delta^{13} \mathrm{C}$ profile that is slightly delayed. The carbon isotopic enrichment in this case is recorded towards the end of the eruptive period.

Significant spikes in the concentration of sulfur (Table 1, Figure 3) and phosphorus (Table 1, Figure 4) are only apparent in tree cores immediately adjacent to and in the ashfall zone of the eruption. Cores obtained at a further distance show no significant enrichment in the concentration of these elements compared to pre-eruptive years (2-tailed t-test, $\alpha=0.05$ ).

\section{Discussion}

The enrichment of $\delta^{13} \mathrm{C}$ values immediately following the eruption in closely adjacent areas inside the ash fall zone is likely due to a combination of two causes: incorporation of mantle-derived carbon dioxide into the local atmosphere and decreased isotopic discrimination due to water stress and exposure to pollutants resulting from volcanic activity. Mantle derived carbon is known to have enriched carbon isotopic values compared to surface sources (Tazieff and Sabroux, 1983). The $\mathrm{CO}_{2}$ gas emitted during volcanic activity will mix with the local atmosphere and enrich its overall carbon isotopic value thus enriching the overall pool of $\mathrm{CO}_{2}$ available to the local flora. The carbon isotopic values of plant tissues tend to exhibit a direct relationship with that of the local $\mathrm{CO}_{2}$ pool (Heaton, 1999).
Exposure of plants to high levels of atmospheric aerosols, $\mathrm{SO}_{2}$, and water stress resulting from non-ideal conditions typically results in stomatal closure and decreased carbon isotopic discrimination during photosynthesis (Farquhar et al., 1982, 1989; Tieszen, 1991; Heaton, 1999). The overall result of this physiological response to stress is enrichment in carbon isotopic values of the plant tissues on the order observed at Parícutin (Farquhar et al., 1989; Tieszen, 1991; Heaton, 1999; Rinne et al., 2010). While the levels of water stress and aerosols were not directly measured during this eruption, emissions of such aerosols and pollutants are typical of volcanic activity (Tazieff and Sabroux, 1983; Johnson et al., 2010) and the ring width measurements from the tree cores suggest decreased growth and tissue production during eruption years (Sheppard et al., 2008). It is therefore likely that the trees experienced some level of environmental stress resulting in the necessary decreased leaf conductance to produce an isotopic enrichment.

It is unlikely that the observed trend in carbon isotopic values during the eruptive years is due to typical yearly variations in climate. As previously mentioned, carbon isotopic variations in plants that result from climate effects are typically due to water stress. Climate records from lake varve chronologies and climate stations within $100 \mathrm{~km}$ of Paricutin (Kienel et al., 2009; NCDC, 2011) show no indications of excessive drought or extreme climate events encompassing the eruptive years. The carbon isotope values from the Rosetta stump which shows the most pronounced enrichment immediately following the eruption do not correlate with mean annual precipitation values $\left(\mathrm{R}^{2}=0.19\right)$ or mean

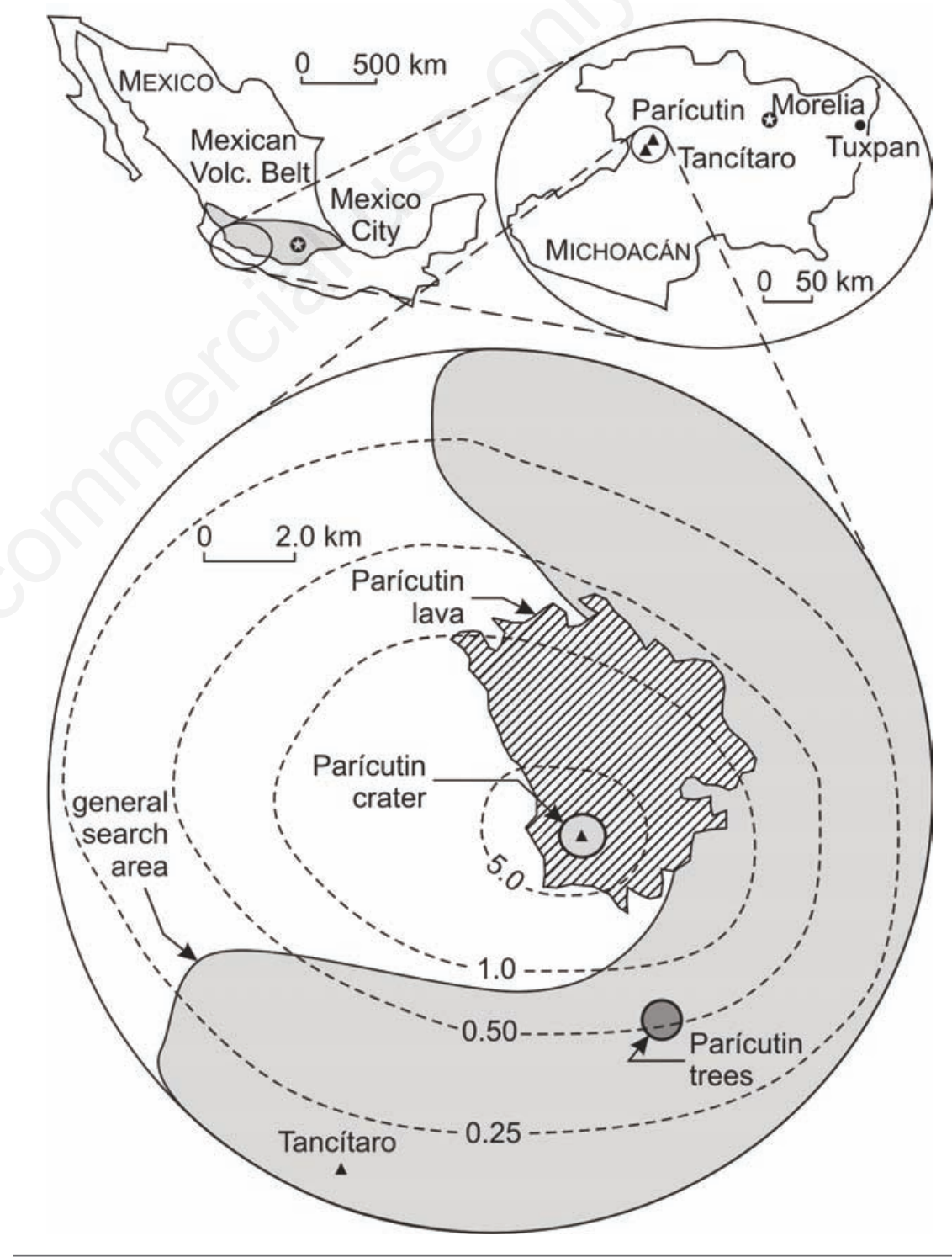

Figure 1. Map depicting the sample locations of tree cores in Parícutin and Tancitaro, Mexico (after Sheppard et al., 2008; reproduced with permission of Steven W. Leavitt, Tree-Ring Research). 
annual temperature $\left(\mathrm{R}^{2}=0.0010\right)$ from nearby climate stations. If these climate variables were responsible for the observed carbon isotope shifts, one would expect yearly correlations with $\delta^{13} \mathrm{C}$ as opposed to the observed multi-year trend towards enrichment followed by a subsequent return to baseline values, a trend which more appropriately correlates to stress induced by the volcanic eruption.

Increased sulfur concentrations in the tree rings from areas closely adjacent to the cinder cone have been previously discussed in depth in Sheppard et al. (2008). In brief, the increased elemental abundance of sulfur is likely due to an elevated flux of sulfur from the eruption in the form of $\mathrm{SO}_{2}$ gas. The sulfur dioxide gas readily reacts to form sulfate salts that adhere to the volcanic ash thus forming sulfur rich aerosols (Rose, 1977; Smith et al., 1982; de Moor et al., 2010). Due to the highly soluble nature of these salts, the sulfates readily enter into the surrounding soil and ecosystem via groundwater when the particulate matter settles to the earth's surface. As dissolved sulfates are the primary form by which plants take in sulfur-bearing compounds, the increased concentrations of sulfates in soil water results in greater overall sulfur uptake by trees and plants (Stevenson, 1986).

The elevated phosphorus concentrations in tree rings from areas closely adjacent to the eruption have also been discussed in detail in Sheppard et al. (2008). These increased concentrations are likely the result of two concurrent factors: soil disturbance due to the eruption with a subsequent release of additional phosphorus into the local environment, and a potential increase in acidity of soils. Phosphorus is often a limiting nutrient for plants as inorganic phosphate species are the only soluble forms of phosphorus which most plants can transport across membranes and incorporate into their tissues (Holford, 1997; Schachtman et al., 1998). Thus the amount of phosphorus available to plants is governed by the inorganic weathering and erosion of phosphate rocks and minerals to produce phosphate species which then move through soils by the slow process of diffusion (Holford, 1997; Schlesinger, 1997; Schachtman et al., 1998). A massive disturbance to the apatite-rich Andisol soils prevalent at Parícutin, such as the emergence of a cinder cone, would release sequestered phosphates as particulate matter which would become mobile in soils upon settling. In addition to an increased concentration of labile phosphates in soils, the gases and aerosols ejected during volcanic activity (such as $\mathrm{SO}_{2}, \mathrm{H}_{2} \mathrm{~S}, \mathrm{HCl}$, and $\mathrm{HF}$ ) are often conducive to increasing soil $\mathrm{pH}$. The quantity of exchangeable $\mathrm{P}$ available to plants for uptake from the soluble phosphorus pool is increased in more acidic conditions (Stevenson, 1986; Holford, 1997). Therefore volcanic conditions may increase the actual amount of $P$ available to plants as well as produce conditions that better facilitate the uptake of $P$ by those plants.

Tree rings from the more distant Tancitaro collection site $(\sim 5 \mathrm{~km}$ from the Parícutin cinder cone) exhibit fluctuations in $\delta^{13} \mathrm{C}$ values but maintain a relative baseline level of elemental sulfur and phosphorus abundance most likely due to differences in the uptake mechanism for these substances. As discussed above, both sulfur and phosphorus are incorporated into the wood primarily via soil uptake and groundwater flow as opposed to direct diffusion of a gaseous compound from the atmosphere as is the case with $\mathrm{CO}_{2}$. The hydrology of this region does not support the transport of sulfur and phosphorus rich ash and groundwater from Parícutin to Tancitaro. Parícutin to the north and Tancitaro to the south, two points of relatively high elevation, are separat-

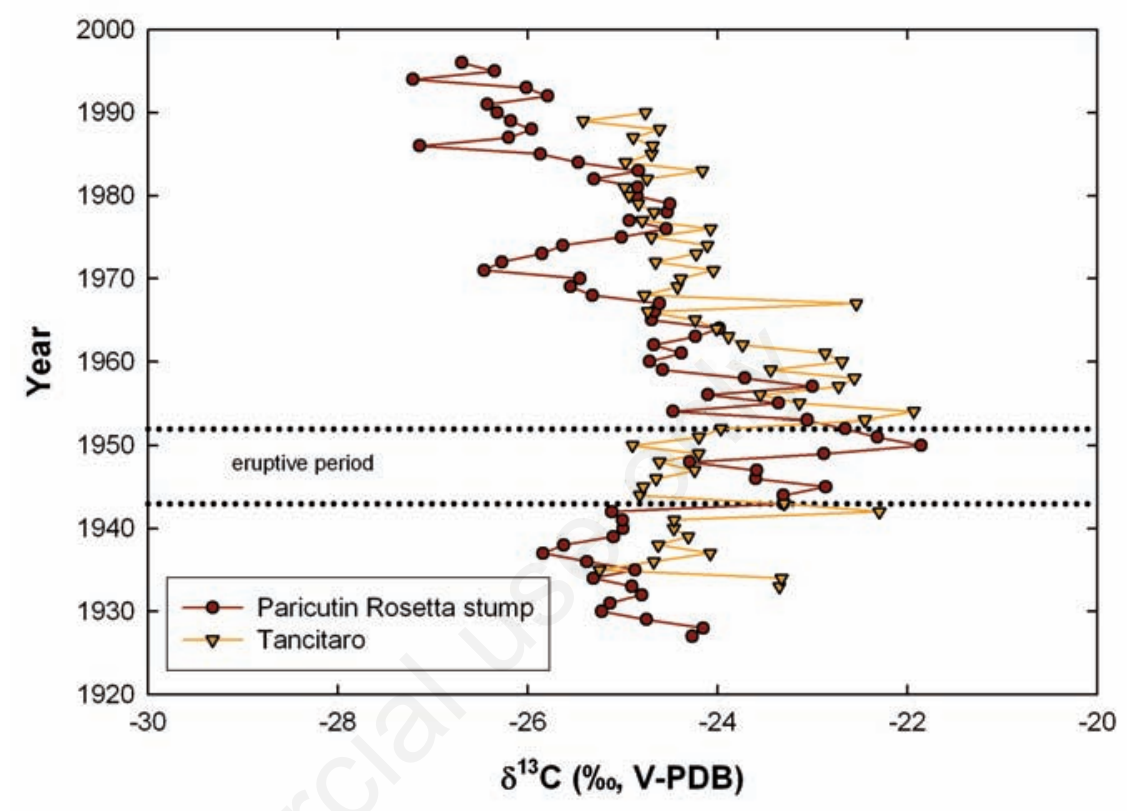

Figure 2. Carbon isotopic values from individual tree rings adjacent to the eruption area (Parícutin Rosetta stump) and $-5 \mathrm{~km}$ from the cinder cone (Tancitaro). All $\delta^{13} \mathrm{C}$ values have an error of $\pm 0.2 \%$ o $(1 \sigma)$.

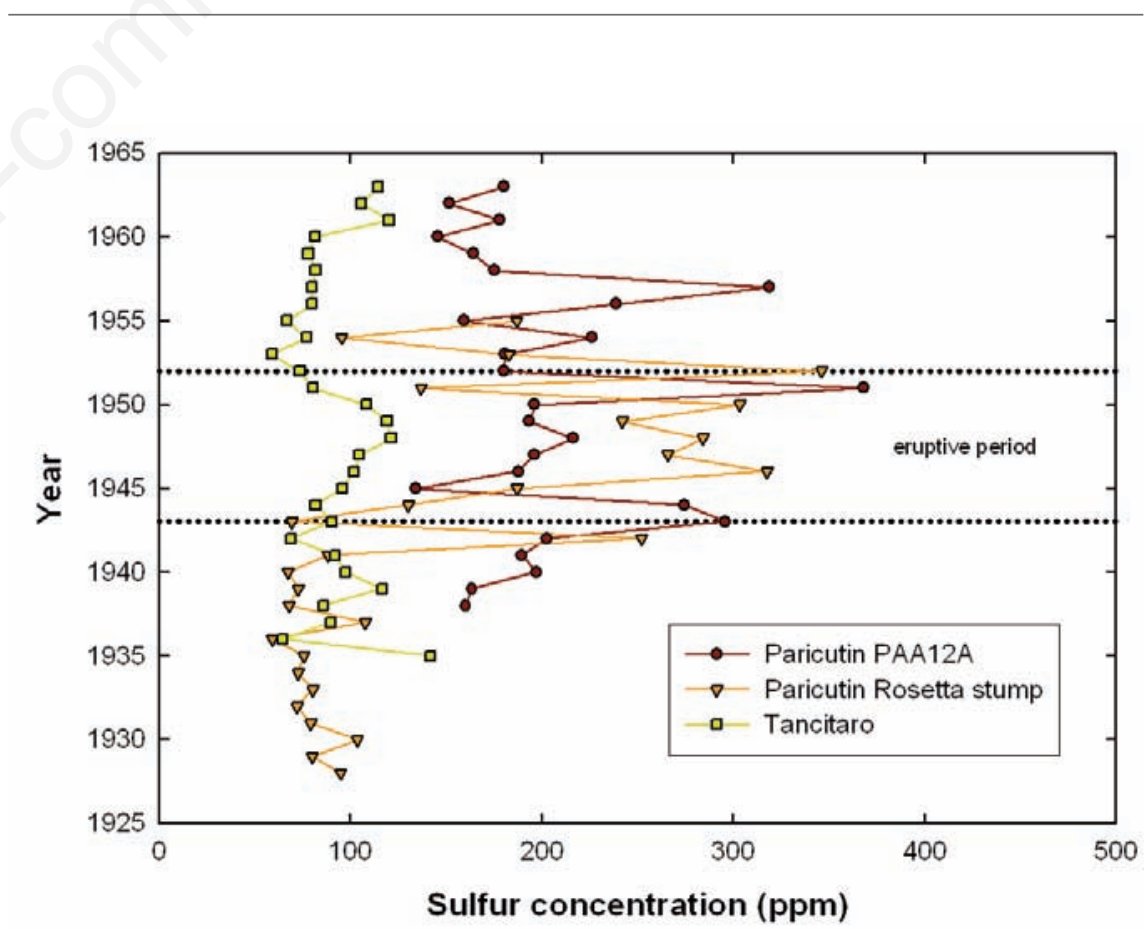

Figure 3. Sulfur concentrations in individual tree rings adjacent to the eruption area (Parícutin PAA12A and Rosetta stump) and $-5 \mathrm{~km}$ from the cinder cone (Tancitaro). 
ed by a lower lying valley, numerous channels and arroyos, and an established watershed divide (Segerstrom, 1950). Surface and ground water in the Parícutin cinder cone area flows primarily to the west into the Rio de Itzicuaro watershed, whereas water flow in the Tancitaro area flows primarily into a more easterly watershed (Segerstrom, 1950). Sediments and ash eroded from the Parícutin site have been redeposited primarily to the west in the Los Reyes floodplain, as opposed to the Tancitaro region. In contrast to the watermediated transport of sulfur and phosphorus, gaseous input from the volcanic eruption is not controlled by watershed divides and topographic features. Atmospheric $\mathrm{CO}_{2}$ more readily mixes and disperses to a wide area, thus allowing an enriched carbon isotopic input from volcanic emissions to be incorporated into Tancitaro vegetation where increases in sulfur and phosphorus elemental abundances are not. This contrast between the behaviours of gaseous $v s$ water-mediated inputs from volcanic eruptions suggests that elemental abundance indicators of volcanic eruptions (such as increased sulfur or phosphorus) must be carefully considered in the context of ash/lava deposition and groundwater flow. This study suggests that tree rings from areas outside the ash/lava deposition zone will not necessarily show increased elemental abundances unless the hydrologic parameters in the area are conducive to transporting these deposited signals to the vegetation. In contrast, gaseous inputs (such as unique isotopic signals) will travel further. A combination of parameters is there- fore critical to establishing a chemical profile within tree rings that is uniquely indicative of volcanic activity.

\section{Conclusions}

This study suggests that a combination of geochemical indicators from tree rings in close proximity to an eruption form a distinct profile indicative of a volcanic event. Enrichment in carbon isotopic values and increased elemental abundances of sulfur and phosphorus from volcanic emissions is incorporated into the woody tissue of plants within the first few years of an eruption. The strength of the recorded signal in the tree rings deceases with distance from the eruption site suggesting that topography, hydrology, and ash/lava flow coverage of an area must be carefully considered when searching for vegetation that is likely to record a volcanic eruption.

Future work on this preliminary project requires additional tree cores and should include the addition of oxygen isotopes, sulfur isotopes, and supplemental elemental abundance analyses of the tree rings. The construction of this multi-layered chemical profile of a known volcanic eruption can then be directly applied to eruptions with controversial dates. Combining dendrochronological dating of individual rings with isotopic and elemental signatures can potentially locate volcanic eruptions to within $\sim 10$ years of the initial eruption event.

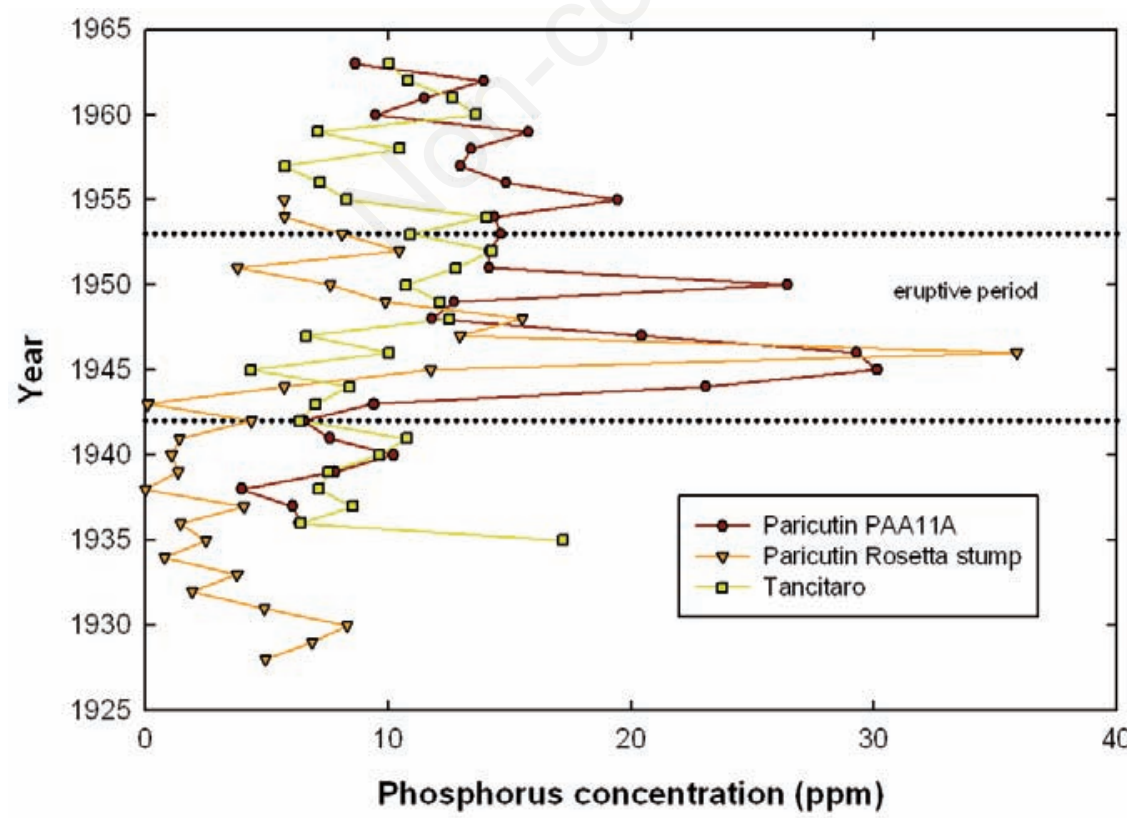

Figure 4. Phosphorus concentrations in individual tree rings adjacent to the eruption area (Parícutin PAA11A and Rosetta stump) and $-5 \mathrm{~km}$ from the cinder cone (Tancitaro).

\section{References}

de Moor JM, Fischer TP, Sharp ZD, Hauri EH, Hilton DR, Atudorei V, 2010. Sulfur isotope fractionation during the May 2003 eruption of Anatahan volcano, Mariana Islands: implications for sulfur sources and plume processes. Geochim Cosmochim Ac 74: 5382-97.

Farquhar GD, Ehleringer JR, Hubick KT, 1989. Carbon isotope discrimination and photosynthesis. Annu Rev Plant Phys 40:503-37.

Farquhar GD, O'Leary MH, Berry JA, 1982. On the relationship between carbon isotope discrimination and the intercellular carbon dioxide concentration in leaves. Aust $\mathrm{J}$ Plant Physiol 9:121-37.

Heaton THE, 1999. Spatial, species, and temporal variations in the ${ }^{13} \mathrm{C} / 12 \mathrm{C}$ ratios of $\mathrm{C}_{3}$ plants: implications for palaeodiet studies. J Archaeol Sci 26:637-49.

Holford ICR, 1997. Soil phosphorus: its measurement, and its uptake by plants. Aust J Soil Res 35:227-39.

Johnson ER, Wallace PJ, Cashman KV, Granados HD, 2010. Degassing of volatiles $\left(\mathrm{H}_{2} \mathrm{O}, \mathrm{CO}_{2}, \mathrm{~S}, \mathrm{Cl}\right)$ during ascent, crystallization, and eruption at mafic monogenetic volcanoes in central Mexico. J Volcanol Geoth Res 197:225-38.

Kienel U, Bowen SW, Byrne R, Park J, Böhnel H, Dulski P, Luhr JF, Siebert L, Haug GH, Negendank JFW, 2009. First lacustrine varve chronologies from Mexico: impact of droughts, ENSO, and human activity since $\mathrm{AD} 1840$ as recorded in maar sediments from Valle de Santiago. J Paleolimnol 42:587-609.

Luhr JF, Simkin T, 1995. Parícutin: the volcano born in a Mexican cornfield. Geoscience Press, Phoenix, Arizona.

NCDC, 2011. National Climate Data Center online data repository. Available from: http://www.ncdc.noaa.gov/oa/wdc/index.ph $\mathrm{p}$ ? name $=$ datasearch

Rinne KT, Loader NJ, Switsur VR, Treydte KS, Waterhouse JS, 2010. Investigating the influence of sulphur dioxide $\left(\mathrm{SO}_{2}\right)$ on the stable isotope ratios $\left(\delta^{13} \mathrm{C}\right.$ and $\left.\delta^{18} 0\right)$ of tree rings. Geochim Cosmochim Ac 74:2327-39.

Rose WI Jr., 1977. Scavenging of volcanic aerosol by ash: atmospheric and volcanologic implications. Geology 5:621-4.

Schachtman DP, Reid RJ, Ayling SM, 1998. Phosphorus uptake by plants: from soil to cell. Plant Physiol 116:447-53.

Schlesinger WH, 1997. Biogeochemistry: an analysis of global change. Academic Press, San Diego, 588 pp.

Segerstrom K, 1950. Erosion studies at Paricutin, State of Michoacan, Mexico. U.S. Government Printing Office, 
Washington, DC, USA.

Sheppard PR, Ort MH, Anderson KC, Elson MD, Vázquez-Selem L, Clemens AW, Little NC, Speakman RJ, 2008. Multiple dendrochronological signals indicate the eruption of Parícutin volcano, Michoacán, Mexico. Tree-Ring Res 64:97-108.
Smith DB, Zielinski RA, Rose WI Jr., Huebert BJ, 1982. Water-soluble material on aerosols collected within volcanic eruption clouds. J Geophys Res 87:4963-72.

Stevenson FJ, 1986. Cycles of soil: carbon, nitrogen, phosphorus, sulfur, micronutrients. John Wiley \& Sons, New York,
380 pp.

Tazieff H, Sabroux JC, 1983. Forecasting volcanic events. Elsevier, Amsterdam, 635 pp. Tieszen LL, 1991. Natural variations in the carbon isotopic values of plants: implications for archaeology, ecology, and paleoecology. J Archaeol Sci 18:227-48. 